\title{
DUCTILITY EVALUATION OF REINFORCED CONCRETE COLUMN MADE OF NORMAL- TO HIGH-STRENGTH CONCRETE UNDER CONSTANT AXIAL LOAD LEVEL COMBINED WITH FLEXURAL LOADING USING NONLINEAR SECTIONAL FIBER BASED MODEL
}

\author{
Bambang Piscesa ${ }^{a^{*}}$, Dwi Prasetyaa ${ }^{a}$ Mudji Irmawana ${ }^{a}$, Harun Alrasyid ${ }^{a}$
}

\begin{abstract}
This study presents the ductility evaluation of reinforced concrete column made of normal-strength material using various empirical stress-strain model with nonlinear sectional fiber based analysis. The purpose is to evaluate the confinement requirement for reinforced concrete column under high axial load level. The concrete strength considered in the analysis are varies from 30 to $70 \mathrm{MPa}$ while the steel reinforcing bar yield strength considered is only $400 \mathrm{MPa}$. The ductility is evaluated by using the customized ductility index measurement. The ratio of the concrete cover to the concrete core is set to 0.1 but not more than $40 \mathrm{~mm}$. Attard and Setunge's concrete constitutive model is used in this investigation. Cover spalling behavior is considered in the analysis by including the restrained shrinkage effect on the concrete strength and the softening behavior. From this study, it was found that extra confinement is necessary to maintain the expected minimum level of ductility.
\end{abstract}

Keywords: High-strength concrete, empirical stress-strain model, fiber-based analysis

\section{INTRODUCTION}

It is well known that the behavior of RC column is greatly affected by the applied axial load level. At the same amount of confinement level, the post-peak behavior of RC column degenerates as the axial load level increases [1-17]. Existing building codes, such as ACI 318-14 [18], CSA A23.3-04 [19], NZS 3101:2006 [20] and SNI 2847-2019 [21], provide additional clause for the minimum confinement reinforcement [22] if the column were loaded with high axial load level. This additional clause was added to ensure the minimum ductility level provided by the confinement rebar still satisfy the minimum requirement.

CSA A23.3 [19] and NZS 3101 [20] standards have considered the axial load effect in the confinement formulation since 2004 and 2006, respectively. The building code SNI 2847 [21] which was used in Indonesia is adopted from ACI 318 [18] building code. ACI 318 [18] have considered this axial load effect in the confinement formulation since 2014. One of the interesting facts is that this additional confinement requirement is applied not only for RC column loaded with high axial load level but also for high-strength concrete (HSC) regardless of the axial load level applied on the column. Therefore, this paper is allegedly trying to find out why additional clause for confinement is required by investigating the ductility level of RC column made of NSC and HSC under varying axial load level.

For that purpose, nonlinear sectional fiber-based analysis is carried out to investigate whether the additional clause for confinement rebar in ACI 318-14 [18] is necessary and is adequate to maintain the same ductility level as low axially loaded RC column. The concrete constitutive model is using the Attard and Setunge's model [23]. The ductility level of the RC column is computed by using the $I_{10}$ ductility measurement $[24,25]$ which is somewhat different than the common method used in ACI 318-14 [18]. To

${ }^{a}$ Lecturer in the Civil Engineering Department, Institut Teknologi Sepuluh Nopember, ITS Campus, Sukolilo, Surabaya 60111, Indonesia. Corresponding author email address: piscesa@ce.its.ac.id maintain the discussion on the effect of the concrete strength, three concrete strengths are investigated.

\section{RESEARCH SIGNIFICANCE}

This paper investigates the ductility level of RC column made of NSC and HSC by using nonlinear sectional fiber-based analysis. The ACI 318-14[18] building code is used to ensure the investigated RC columns are designed conform to the design guidelines. The axial load level investigated varies from zero up to eighty percent of the RC column concrete capacity. The measured ductility level is computed using the $I_{10}$ ductility index. This $I_{10}$ ductility index $[24,25]$ use the energy under the load-deflection curve which is a more reasonable approach to measure the ductility level of RC column.

\section{METHODOLOGY}

The research methodology in this paper consisted of four stages. The first stage of this research is the input data preparation. At this stage, the corresponding RCHSC data are prepared. The data consisted of the strength of concrete and rebar materials, the geometry configurations of the columns, and the rebar configuration for both the longitudinal and transversal directions. The ratio of the longitudinal reinforcement is set to $1.5 \%$ and the number of longitudinal rebar is set to eight. Therefore, the diameter of rebar may not conform with any standard size but is explicitly set such that the demanded ratio is exactly equal.

The transversal reinforcement is designed based on ACI 318-14 [18] for minimum confinement rebar. Two configurations of the transverse rebar are investigated. The pitch spacing is set to $100 \mathrm{~mm}$. The diameter of the transverse rebar is computed such that the value for the confinement rebar is in exact match with required rebar area based on ACI 318-14 [18]. The column geometry considered is square with the width of the column is 400 $\mathrm{mm}$. The cover thickness for $400 \mathrm{~mm}$ width column is set to $40 \mathrm{~mm}$ which is ten percent of the total width. 
In the second stage, the existing Attard and Setunge's model formulation is modified to include the effect of cover spalling. The cover spalling effect is only applied for the concrete cover element while the concrete core element is computed by considering the confinement provided by the transverse steel reinforcement. In the third stage, nonlinear sectional fiber-based analysis is carried out with varying axial load level, as well as the transverse steel rebar configurations. In the fourth stage, the ductility index for each moment-curvature curve was computed by considering the average nominal strain of the section.

\section{A. MINIMUM CONFINEMENT REINFORCEMENT BASED ON ACI 318-14 [18]}

ACI 318-14 [18] provides minimum confinement reinforcement to ensure the ductility of $\mathrm{RC}$ column under combined axial load and bending moment can still be satisfied. In the previous ACI 318 design codes [26], only two equations should be satisfied. These equations are:

$$
\begin{gathered}
\frac{A_{\mathrm{sh}}}{s b_{c}}=0.3\left(\frac{A_{\mathrm{g}}}{A_{\mathrm{ch}}}-1\right) \frac{f_{\mathrm{c}}^{\prime}}{f_{\mathrm{yh}}} \\
\frac{A_{\mathrm{sh}}}{s b_{c}}=0.09 \frac{f_{\mathrm{c}}^{\prime}}{f_{\mathrm{yh}}}
\end{gathered}
$$

In the above, $A_{\mathrm{sh}}$ is the area of the transverse steel rebar in $\mathrm{mm}^{2}, s$ is the pitch spacing in $\mathrm{mm}, b_{\mathrm{c}}$ is the width of the column core in mm, $A_{\mathrm{g}}$ is the gross cross sectional area of the column in $\mathrm{mm}^{2}, A_{\mathrm{ch}}$ is the core cross sectional area of the column in $\mathrm{mm}^{2}, f_{\mathrm{c}}$ is the concrete compressive strength in $\mathrm{MPa}$ and $f_{\mathrm{yh}}$ is the transverse steel yield strength in MPa.

In the case of the ratio of the factored axial load $\left(P_{\mathrm{u}}\right)$ over the gross sectional capacity of the concrete $\left(A_{\mathrm{g}} f_{\mathrm{c}}\right)$ higher than 0.3 or for concrete with compressive strength higher than equal to $70 \mathrm{MPa}$, additional clause was provided by ACI 318-14 [18]:

$$
\frac{A_{\mathrm{sh}}}{s}=0.2 k_{\mathrm{f}} k_{\mathrm{n}} \frac{P_{\mathrm{u}}}{f_{\mathrm{yt}} A_{\mathrm{ch}}}
$$

where $k_{\mathrm{n}}$ is a factor that decrease the required confinement for column with closely spaced longitudinal reinforcing bar, $k_{\mathrm{f}}$ is the factor that consider the brittleness of the concrete material for HSC. The expression for $k_{\mathrm{n}}$ and $k_{\mathrm{f}}$ were proposed by Legeron and Paultre [22] and are:

$$
\begin{gathered}
k_{f}=\frac{f_{\mathrm{c}}^{\prime}}{175}+0.6 \geq 1.0 \\
k_{\mathrm{n}}=\frac{n_{1}}{n_{1}-2}
\end{gathered}
$$

In the above, $n_{1}$ is the number of longitudinal bars. Since the pitch spacing was determined $(100 \mathrm{~mm})$ and with the number of ties leg $\left(n_{\mathrm{h}}\right)$ is three, the diameter of the transverse steel reinforcing bar can be calculated as:

$$
d_{\mathrm{h}}=\sqrt{\frac{4 s \chi}{n_{\mathrm{h}} \pi}}
$$

where $\chi$ is the required $A_{\mathrm{sh}} / s$ computed using Eqns.(1)(2) and (3).

\section{B. MODIFICATION IN THE STRESS-STRAIN MODEL TO INCLUDE THE COVER SPALLING BEHAVIOR}

Cover spalling behavior plays an important role on the behavior of RC column especially under high axial load. The existence of restrained shrinkage strain [27, 28] at the cover shell provides an initial tensile pressure which lowered the concrete compressive strength of the concrete cover. In addition, the weak plane at the interface between the cover shell and the concrete core can exist especially if the configuration of both the longitudinal and the transverse steel rebars is sufficiently dense. In normalstrength RC column, when the cover spalling occurred, the cover shell still carries some portion of axial load [29].

To include the cover spalling behavior in the stress-strain model due to restrained shrinkage, some properties of the stress-strain models should be modified. In [28], there are three basic properties should be adjusted for the concrete constitutive model. These properties are the uniaxial peak concrete compressive strength, the uniaxial peak axial strain, and the uniaxial strain at the inflection point of the softening curve. In this paper, the concrete constitutive model which can cope with three basic parameter in the above are the model of Attard and Setunge [23].

\section{NONLINEAR SECTIONAL FIBER BASED MODEL}

To evaluate the behavior of $\mathrm{RC}$ column under combined axial load and bending moment, an analytical simulation tool is required. In this paper, a nonlinear sectional fiber-based model analysis using MatLab is used [30]. The RC column section is discretized using Constant Strain Triangle (CST) and the cover and cover elements are differentiated. Figure 1 shows an example of RC column meshed using the CST element [31]. The red circle on Figure 1 represent the longitudinal bar position.

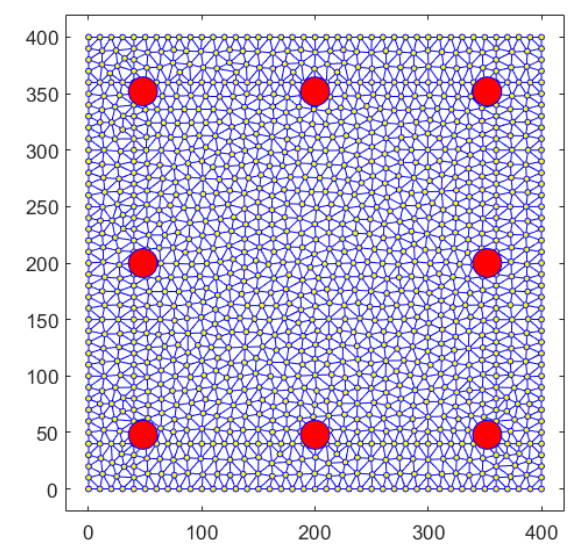

Figure 1 Discretized Meshed Fiber-Based Element with Triangular Constant-Strain-Triangle (CST)

The axial force and the bending moment of the cross section can be computed by [30]:

$$
\begin{gathered}
F=\sum_{i}^{\text {nele }} \sigma_{i} A_{i} \\
M_{y y}=\sum_{i}^{\text {nele }} \sigma_{i} A_{i}\left(y_{i}-\bar{y}\right)
\end{gathered}
$$




$$
M_{x x}=\sum_{i}^{\text {nele }} \sigma_{i} A_{i}\left(x_{i}-\bar{x}\right)
$$

where $F$ is the axial force, $M_{y y}$ is the moment in the $\mathrm{Y}$ direction, $M_{\mathrm{xx}}$ is the moment in the $\mathrm{X}$-direction, $\sigma_{i}$ is the axial stress in the element, $A_{\mathrm{i}}$ is the area of the element, $y_{\mathrm{i}}$ and $x_{\mathrm{i}}$ is the centroid location of the element, $\bar{y}$ and $\bar{x}$ is the centroid of the whole cross section.

\section{MEASUREMENT OF THE DUCTILITY INDEX}

To measure the ductility index of RC, an extended formulation for $I_{10}$ ductility measurement is used. $I_{10}$ ductility measurement often used to measure the ductility of RC column under either concentric or eccentric loading. The internal work done in $\mathrm{I}_{10}$ can be defined by [32]:

$$
\int_{R}\left(N \varepsilon_{\text {avg }}+N e \kappa\right) d x=\int_{R} N\left(\varepsilon_{\text {avg }}+e \kappa\right) d x
$$

where $\varepsilon_{\text {avg }}$ is the average strain, $N$ is the axial load, $e$ is the load eccentricity and $\kappa$ is the curvature. For RC column fixed supported at the base and is loaded under constant axial load and were displaced horizontally, the internal work done can be computed by:

$$
\int_{R}\left(N \varepsilon_{a v}+(N e+H L) \kappa\right) d x=\int_{R}\left(N \varepsilon_{a v}+M \kappa\right) d x
$$

where $H$ is the horizontal load, $L$ is the column height and $M$ is moment acting on the cross section of the column. The second term in Eqn.(11) above consisted of a second order moment plus the primary bending moment. By noting that the axial load is constant, the nominal strain can be reduced to:

$$
\xi=\frac{\left(N \varepsilon_{a v}+M \kappa\right)}{N}
$$

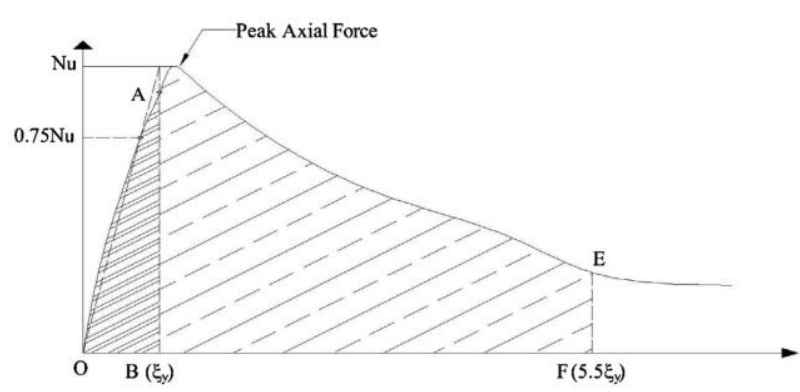

Figure 2 The axial force versus the combined nominal strain $(\xi)$ curve [32]

Figure 2 shows the axial force as function of the combined nominal strain $(\xi)$ curve. In the case of axially loaded RC column and by assuming a perfectly elastoplastic responses, the value for $I_{10}$ must be exactly equal to ten. Therefore, the ultimate strain should be at least 5.5 times the nominal yield strain. The area of $\mathrm{OAB}$ with normalized $N_{\mathrm{u}}$ equal to one would be 0.5 . The area of OAEF would be equal to 5.0. By dividing area OAEF with $\mathrm{OAB}$ the value for $I_{10}$ is exactly equal to 10 [24].

From Figure 2, it should be noted that the initial secant modulus of the load-nominal strain curve is measured at $75 \%$ of the maximum load applied on the column. In AS3600-2018 [33], the value for $I_{10}$ ductility index used to ensure the column is sufficiently ductile is set to 5.6.
This means that the confinement reinforcement should be provided such that the value for $I_{10}$ must be greater than 5.6.

In ACI 318-14 [18], the ductility measurement is measured from the peak once the peak load reduced to $85 \%$ of the maximum capacity. By including the softening responses at a nominal strain 5.5 times higher than the nominal yield strain gives a minimum ductility index value equal to 9.33 (see Figure 3). It is therefore in this paper, the ductility index measured using ACI 318-14 [18] codes is measured using $I_{\mathrm{M} 9.33}$. If the investigated columns have the value of $I_{\mathrm{M} 9.33}$ less than 9.33 means that the columns are assumed to not have sufficient ductility based on ACI 318-14 [18].

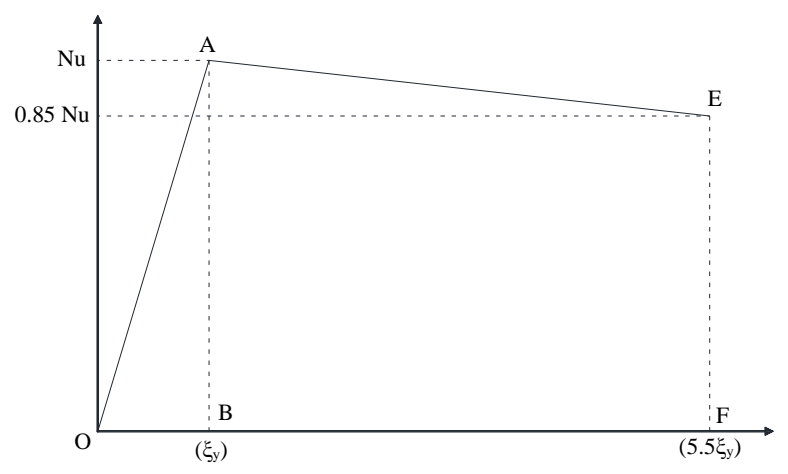

Figure 3 Used axial force versus the combined nominal strain $(\xi)$ curve for measuring ductility index

\section{ANALYSIS AND DISCUSSIONS}

The computed $I_{10}$ ductility index as functions of the axial load level $\left(P_{\mathrm{u}} / f_{\mathrm{c}} A_{\mathrm{g}}\right)$ are shown in Figures 4, 5 and 6 for 30, 50 and $70 \mathrm{MPa}$ concrete, respectively. The confining rebar for those concrete strength are designed only using Eqns.(1) and (2) plus two ratios of Ash/s with nonconforming design guidelines $(1.01 \mathrm{~mm}$ and $1.57 \mathrm{~mm})$. As shown in Figure 4, the RC columns design using Eqns.(1) and (2) show the $I_{10}$ value greater than 9.33 which means for $30 \mathrm{MPa}$ concrete, additional confinement reinforcing bar as stated in ACI 318-14 [18] is not necessary.

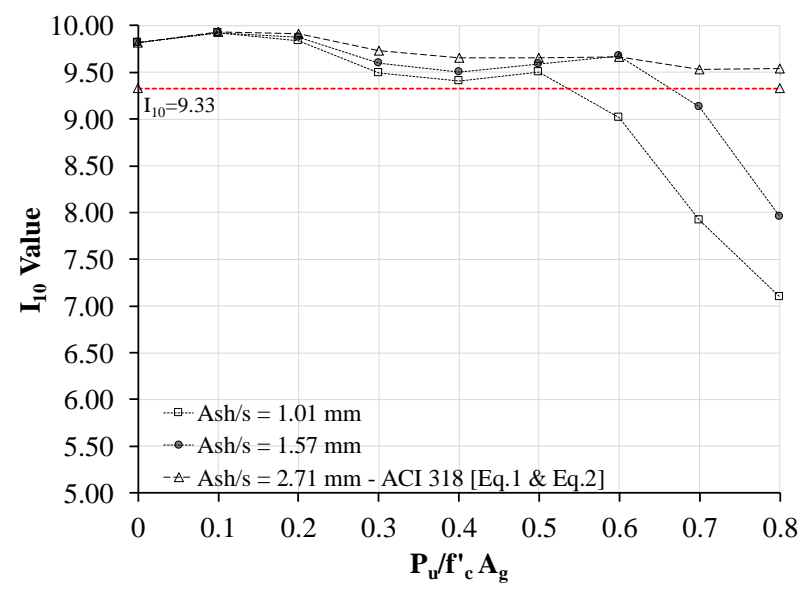

Figure 4 The $I_{10}$ ductility index versus the RC column axial load level for $30 \mathrm{MPa}$ concrete 
For non-conforming confinement rebar, the $I_{10}$ value drops when the axial load level ratio is greater than 0.5 . However, as the concrete strength increases, the $I_{10}$ value for $50 \mathrm{MPa}$ drops below 9.33 at the axial load level ratio higher than 0.6 and for $70 \mathrm{MPa}$ drops at the axial load level ratio higher than 0.5 . This finding shows that as the concrete strength increases, the additional clause for the confinement rebar is necessary. It is expected that as the concrete strength goes higher, the axial load level ratio which shows the $I_{10}$ value less than 9.33 will be lower.

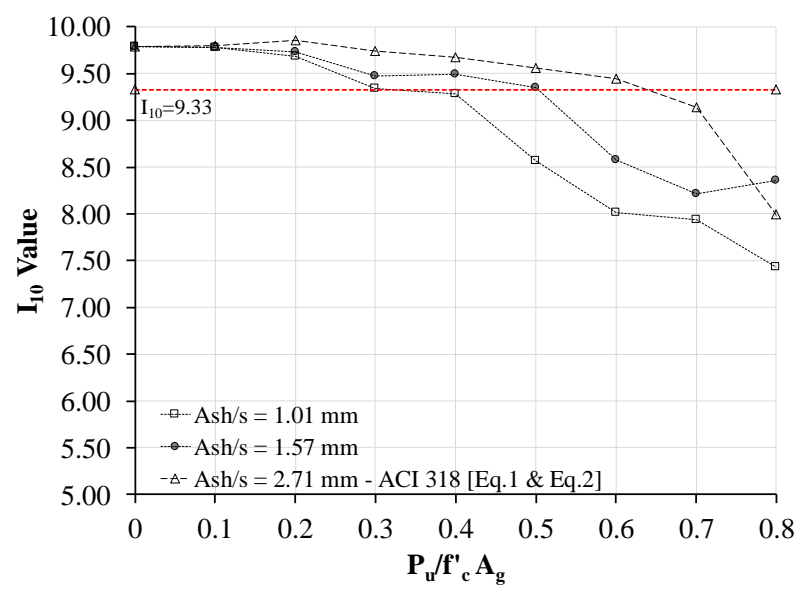

Figure 5 The $I_{10}$ ductility index versus the RC column axial load level for $50 \mathrm{MPa}$ concrete

Figure 7 shows the $I_{10}$ ductility index as function of the axial load level ratio for $70 \mathrm{MPa}$ concrete designed using Eqns. (1)(2) and (3). As shown in Figure 7, using the additional clause for confinement rebar does significantly improve the ductility level of the RC column. The $I_{10}$ value is only barely lower than 9.33 when the axial load level ratio between 0.5 to 0.6. Figures 8 and 9 shows the axial force as function of the combined axial strain for $70 \mathrm{MPa}$ concrete design using only Eqn. (1) and (2), and Eqns. (1)(2) and (3), respectively. As shown in Figure 8 , the softening response of the RC column was observed for axial load level ratio higher than 0.4. Cover spalling behavior is observed when the axial load level ratio is greater than 0.4 .

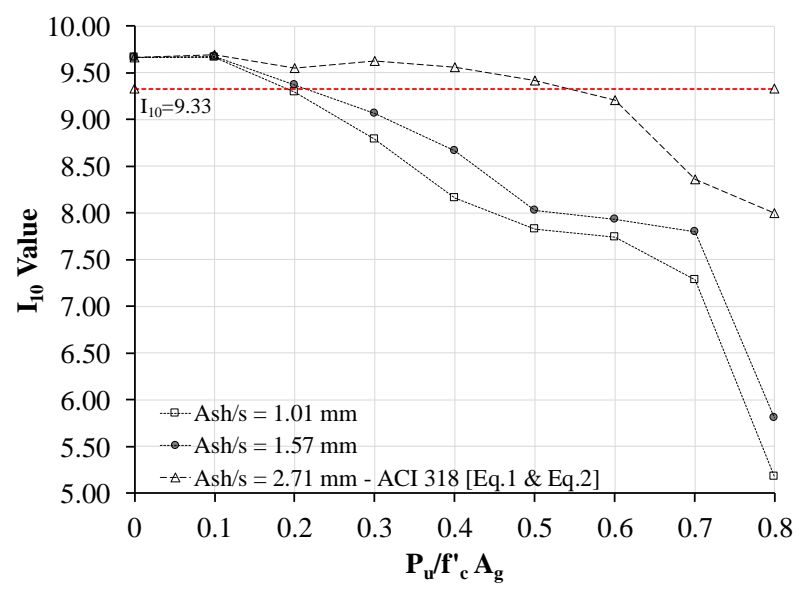

Figure 6 The $I_{10}$ ductility index versus the RC column axial load level for $70 \mathrm{MPa}$ concrete using Eqns. 1 and 2

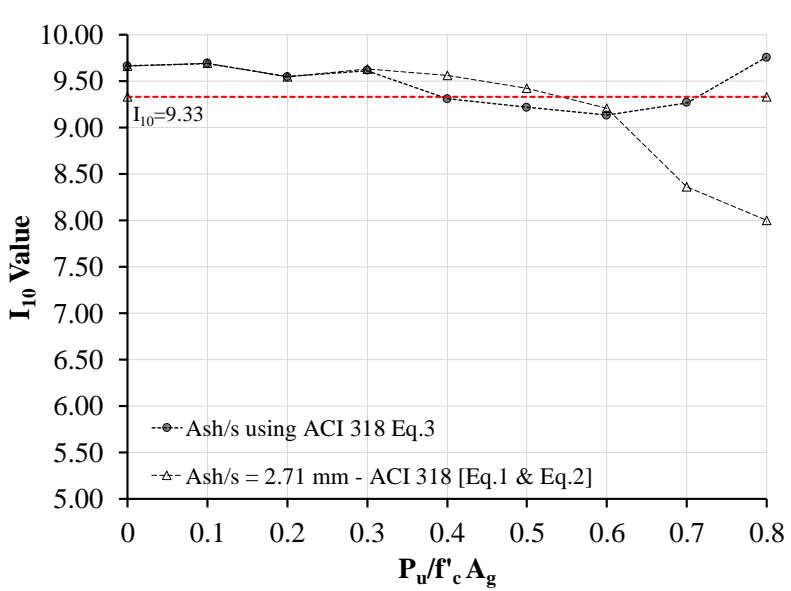

Figure 7 The $I_{10}$ ductility index versus the RC column axial load level for $70 \mathrm{MPa}$ concrete using Eqn.1\&2 and Eqn.3

On the other hand, in Figure 9, a slight softening response only occurred when the axial load level ratio between 0.2 to 0.3 . This can be understood because of the softening response on the cover elements under flexural loadings. As the axial load level ratio is further increased, the softening response changed to hardening.

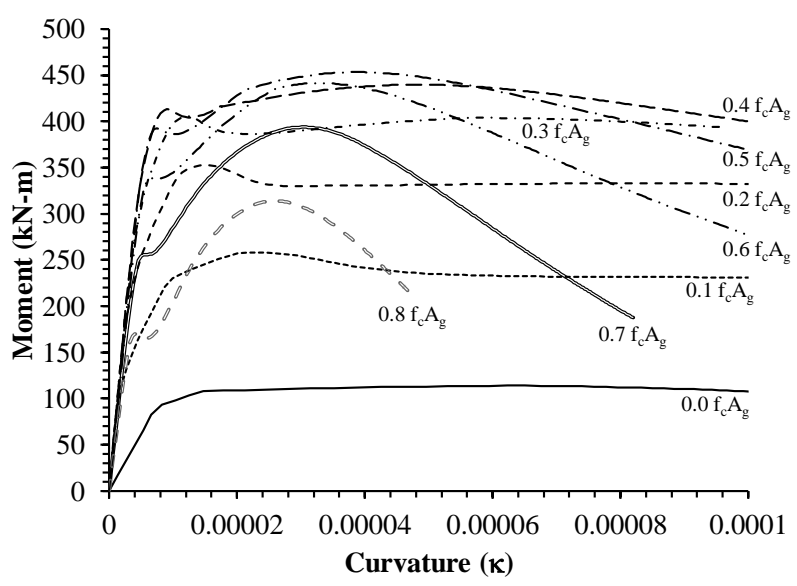

Figure 8 The bending moment capacity versus curvature for $70 \mathrm{MPa}$ concrete using Eqn.1 and Eqn.2

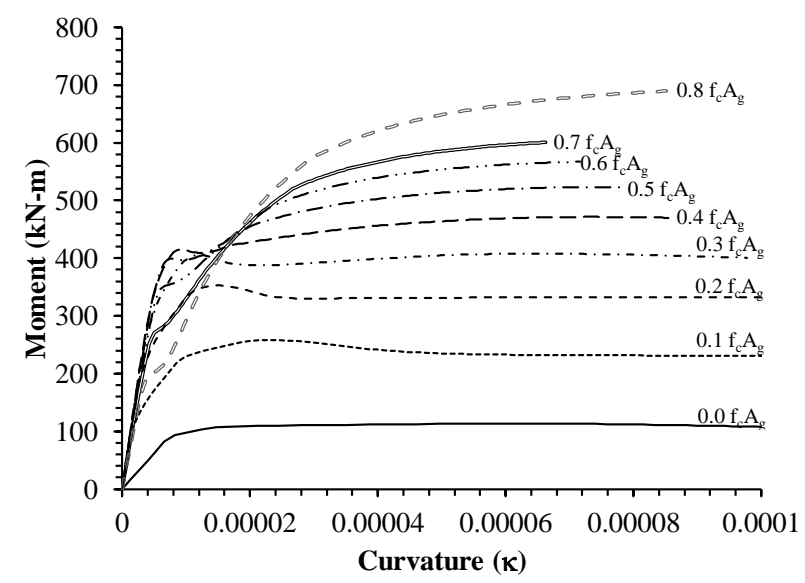

Figure 9 The bending moment capacity versus curvature for $70 \mathrm{MPa}$ concrete using Eqn.3 


\section{CONCLUSIONS}

This paper had presented the axial ductility level of RCcolumn made of HSC evaluated using the nonlinear sectional fiber-based model. Energy based ductility index $[24,25]$ was used to evaluate the ductility level of RCcolumn. The investigated RC columns were designed based on ACI 318-14 [18]. One group was designed using only the first two confinement equations while the other group was designed based on all the three confinement equations. From the investigation, it was found that for normal strength concrete, the additional clause for axial load level ratio higher than 0.3 was not necessary. However, for medium- to high-strength concrete, the additional clause for confinement rebar was required to ensure the minimum ductility level was achieved. Further investigation for RC column made of very high-strength concrete, as well as RC column with different cross section configuration should be investigated.

Furthermore, the use of size-dependent empirical concrete constitutive model [34], inclusion of the confining pressure and lateral strain dependent analytical model [35], as well as other behavior impacted phenomena such as buckling of longitudinal bars [36, 37] should be considered in the future. To further verify the numerical simulation carried out in this paper, numerical investigation using a more sophisticated concrete constitutive model [38-40] and numerical simulation tool [41, 42] which consider the cover spalling [28] should be carried out in the future.

\section{REFERENCES}

[1] H. Tanaka, "Effect of lateral confining reinforcement on the ductile behaviour of reinforced concrete columns," 1990.

[2] S. A. Sheikh and C.-C. Yeh, "Tied concrete columns under axial load and flexure," Journal of Structural Engineering, vol. 116, pp. 27802800, 1990.

[3] H. Muguruma and F. Watanabe, "Ductility improvement of high-strength concrete columns with lateral confinement," Special Publication, vol. 121, pp. 47-60, 1990.

[4] S. Sugano, T. Nagashima, H. Kimura, A. Tamura, and A. Ichikawa, "Experimental studies on seismic behavior of reinforced concrete Members of High-strength Concrete," Special Publication, vol. 121, pp. 61-88, 1990.

[5] H. Muguruma, M. Nishiyama, F. Watanabe, and H. Tanaka, "Ductile behaviours of high strength concrete columns confined by high strength transverse reinforcement," Special Publication, vol. 128, pp. 877-892, 1991.

[6] S. A. Sheikh and S. S. Khoury, "Confined concrete columns with stubs," ACI Structural Journal, vol. 90, pp. 414-414, 1993.

[7] J. H. Thomsen and J. W. Wallace, "Lateral load behavior of reinforced concrete columns constructed using high-strength materials," Structural Journal, vol. 91, pp. 605-615, 1994.
[8] T. M. Pallewatta, P. Irawan, and K. Maekawa, "Effectiveness of laterally arranged reinforcement on the confinement of core concrete," in Proceedings-Japan Society of Civil Engineers, 1995, pp. 297-297.

[9] S. Sugano, "Seismic Behavior of Reinforced Concrete Columns which used Ultra-HighStrength Concrete," Eleventh World Conference on Earthquake Engineering, Paper No. 1383, 1996.

[10] Y. Xiao and A. Martirossyan, "Seismic performance of high-strength concrete columns," Journal of structural Engineering, vol. 124, pp. 241-251, 1998.

[11] O. Bayrak and S. A. Sheikh, "Confinement reinforcement design considerations for ductile HSC columns," Journal of Structural Engineering, vol. 124, pp. 999-1010, 1998.

[12] K. Maekawa and X. An, "Shear failure and ductility of RC columns after yielding of main reinforcement," Engineering Fracture Mechanics, vol. 65, pp. 335-368, 2000.

[13] F. Legeron and P. Paultre, "Behavior of highstrength concrete columns under cyclic flexure and constant axial load," Structural Journal, vol. 97, pp. 591-601, 2000.

[14] P. Paultre, F. Légeron, and D. Mongeau, "Influence of concrete strength and transverse reinforcement yield strength on behavior of highstrength concrete columns," Structural Journal, vol. 98, pp. 490-501, 2001.

[15] Y.-K. Yeh, Y. L. Mo, and C. Yang, "Seismic performance of rectangular hollow bridge columns," Journal of Structural Engineering, vol. 128, pp. 60-68, 2002.

[16] T.-H. Kim, K.-M. Lee, Y.-S. Chung, and H. Shin, "Seismic damage assessment of reinforced concrete bridge columns," Engineering Structures, vol. 27, pp. 576-592, 2005.

[17] P. Paultre, R. Eid, H. I. Robles, and N. Bouaanani, "Seismic performance of circular high-strength concrete columns," ACI Structural Journal, vol. 106, 2009.

[18] A. C. Institute, Building Code Requirements for Structural Concrete (ACI 318-14): Commentary on Building Code Requirements for Structural Concrete (ACI 318R-14): an ACI Report: American Concrete Institute. ACI, 2014.

[19] C. S. Association, Design of concrete structures: Mississauga, Ont.: Canadian Standards Association, 2004.

[20] N. Z. Standards, Concrete structure standard-the design of concrete structures incorporating amendment No. 1 \& 2 (NZS 3101: Part 1: 2006A1\&A2): SNZ Wellington, New Zealand, 2006.

[21] B. S. Nasional, Persyaratan beton struktural untuk bangunan gedung (SNI 2847: 2019), 2019 (Draft).

[22] P. Paultre and F. J. J. o. s. e. Légeron, "Confinement reinforcement design for reinforced concrete columns," vol. 134, pp. 738749, 2008. 
[23] M. Attard and S. Setunge, "Stress-strain relationship of confined and unconfined concrete," ACI Materials Journal, vol. 93, 1996.

[24] S. J. Foster and M. M. Attard, "Experimental tests on eccentrically loaded high strength concrete columns," Structural Journal, vol. 94, pp. 295-303, 1997.

[25] S. J. Foster and M. M. Attard, "Strength and ductility of fiber-reinforced high-strength concrete columns," Journal of Structural Engineering, vol. 127, pp. 28-34, 2001.

[26] A. C. Institute, Building code requirements for structural concrete (ACI 318-11) and commentary, 2011.

[27] S. J. Foster, J. Liu, and S. A. Sheikh, "Cover spalling in HSC columns loaded in concentric compression," Journal of Structural Engineering, vol. 124, pp. 1431-1437, 1998.

[28] B. Piscesa, M. M. Attard, D. Prasetya, and A. K. Samani, "Modeling cover spalling behavior in high strength reinforced concrete columns using a plasticity-fracture model," Engineering Structures, vol. 196, p. 109336, 2019.

[29] S. A. Sheikh, "Effectiveness of rectangular ties as confinement steel in reinforced concrete columns," 1980.

[30] B. Piscesa, M. Attard, P. Suprobo, and A. Samani, "Investigation on the fiber based approach to estimate the axial load carrying capacity of the circular concrete filled steel tube (CFST)," in IOP Conference Series: Materials Science and Engineering, 2017, p. 012017.

[31] D. L. Logan, A first course in the finite element method: Cengage Learning, 2011.

[32] A. K. Samani, M. M. Attard, and S. J. Foster, "Ductility in concentrically loaded reinforced concrete columns," Australian Journal of Structural Engineering, pp. 1-14, 2015.

[33] A. Standard, Concrete structures, 2018.

[34] A. Samani and M. Attard, "A Stress-Strain Model for Uniaxial and Confined Concrete under Compression," Engineering Structures, vol. 41, pp. 335-349, August 2012.

[35] A. K. Samani and M. M. Attard, "Lateral Strain Model for Concrete under Compression," ACI Structural Journal, vol. 111, 2014.

[36] R. P. Dhakal and K. Maekawa, "Path-dependent cyclic stress-strain relationship of reinforcing bar including buckling," Engineering Structures, vol. 24, pp. 1383-1396, 2002.

[37] M. P. Berry and M. O. Eberhard, "Practical performance model for bar buckling," Journal of Structural Engineering, vol. 131, pp. 1060-1070, 2005.

[38] B. Piscesa, "Modeling confined concrete using plasticity formulation," PhD. Thesis, School of Civil and Environmental Engineering, The University of New South Wales, Sydney, Australia, 2018.

[39] B. Piscesa, M. Attard, A. Samani, and S. Tangaramvong, "Plasticity Constitutive Model for Stress-Strain Relationship of Confined
Concrete," ACI Structural Journal, vol. 114, p. 361, 2017.

[40] B. Piscesa, M. M. Attard, and A. K. Samani, "A lateral strain plasticity model for FRP confined concrete," Composite Structures, vol. 158, pp. 160-174, 2016.

[41] B. Piscesa, M. M. Attard, and A. K. Samani, "Three-dimensional Finite Element Analysis of Circular Reinforced Concrete Column Confined with FRP using Plasticity Model," Procedia Engineering, vol. 171, pp. 847-856, 2017.

[42] B. Piscesa, M. M. Attard, and A. K. Samani, "3D Finite element modeling of circular reinforced concrete columns confined with FRP using a plasticity based formulation," Composite Structures, vol. 194, pp. 478-493, 2018. 